\title{
Is China Playing Fair with Its Economic and Trade Policy?
}

\author{
Greg Carrington, Balasundram Maniam, and Geetha Subramaniam
}

\begin{abstract}
China is still progressing from a Marxist-planned economy towards a market-based capitalist economy. During its transition, China has enjoyed an incredible growth rate in GDP. In fact it has been estimated by various sources that its growth for decades has been at least $8 \%$, and possibly up to $17 \%$, and still rising. This paper attempts to firstly analyse if China can continue to retain these rates in the near future and more importantly, is China playing fair in the global market. Some argue that they are not, especially in three areas: international trade dumping, exporting inferior products, and currency manipulation. This paper will look at these three activities carefully to see if China is indeed cheating and not playing fair in the world stage.
\end{abstract}

Index Terms - China trade policies. unfair trade practices, dumping, and currency manipulation.

\section{INTRODUCTION}

Is China "cheating" the United States (US) and other countries to have an unfair advantage? Any very successful competitor in the world economy is, by definition, a threat to its competitors - given the limited resources of the world. China has experienced rapid economic growth in recent decades. According to [1], over half of the world's products (including everything put together from pieces) come from China, with its growth rate of exports at seventeen percent annually over twenty-nine years. India is often mentioned along with China in talks of growing nations, but China's growth in annual trade is larger than India's total annual trade [2].

While China may be an economic threat to its competitors, including the US, the questions posed by this study is whether China is playing fair or "cheating" the US. Cheaters in the economy are those competitors who grab an unfair advantage in securing resources in the game of worldwide commerce. During the 2012 US presidential campaign, the economic relationship of the two countries was a popular topic in the media and among the candidates. It was repeatedly suggested that China was guilty of unfair tactics and of cheating the US.

This paper begins with a literature review and then reviews the economic background of China to gain an understanding of how the business and ethical culture developed. Next, the paper defines cheating and identifies the three primary ways that China is engaging in "cheating" activities. Additional unethical business practices occurring in China are also discussed. Based on the historical references and secondary

Manuscript received June 23, 2014; revised August 20, 2014.

Greg Carrington, Bala Maniam, and Geetha Subramaniam are with the Sam Houston State University, USA (e-mail: GBA_BXM@shsu.edu, geethamaniam@gmail.com). research outlined in this paper, the assertion of this paper is that China has indeed cheated the US - and is probably still doing so.

\section{LITERATURE REVIEW}

Ref. [1] further discusses ethics in the Chinese business setting and how they have changed over time. This paper reviews China's migration to capitalism and specifically focuses on the evolution of business ethics in China. Lu presents considerable evidence that the ethical environment in China makes cheating possible and even likely. According to $\mathrm{Lu}$, after the introduction of economic reforms in 1978, the Chinese government was known to often look the other way when illegal investments were made so as not to scare off its budding capitalists. Any behavior would be allowed as long as the outcome was beneficial in the government's view. As reforms progressed, throughout the 1980's and 1990's, there was still no specific effort by the government to enhance business ethics as the country moved from its planned economy to a market driven one. However, there was increased "conversation" about ethical business practices. After 2001, when China joined the World Trade Organisation and began adopting its requirements, business ethics began to receive increased attention. This new emphasis was increased further after several "scandals" regarding contaminated products exported by China were widely publicised. Lu suggests that today, business ethics have moved from purely theoretical concepts into actual practice in Chinese companies. The concepts have moved from academia into the government, companies, citizens, and laws.

The idea that corporate social responsibility (CSR) is gaining a foothold in China was addressed by both [3] and [4] [4] suggests that the concept of CSR is growing in China but it was borrowed from the West. CSR is the idea of focusing not only on profits, but also on social and environmental responsibilities. Both papers suggest a move, in the last decade or so, to a wider perspective - beyond just a goal of increasing GDP to a broader goal of a harmonious society. According to [3], the concept of CSR has grown to become a full-blown body of research and science in China.

Ref. [5] most closely relates to this paper where he provides a detailed and lengthy itemisation of specific instances of cheating by China, with particular focus on the act of dumping underpriced products on many different countries, including the United States. Mastel also addresses the anti-dumping and countervailing duty (AD-CVD) laws of the US. Along the same line, [6] provided an in-depth look at the case of Chinese steel dumping.

In addition, [7] discuss the International Monetary Fund (IMF) and its accusations against China for defeating its currency. Using regression analysis, they were able to show 
that China fixed the value of their currency to move with the value of the US dollar. [8] also discusses the concept of currency manipulation in developing countries and how the currencies of nations should move if allowed to move freely. Finally, [9] provides details of corporate fraud in China, and the related audit failures involving international CPA firms.

\section{CHINA's BACKGROUND}

Prior to 1979, China's economy was primarily a centrally-planned economy where the state controlled production, prices, and allocation of resources through most of the economy. Nearly seventy-five percent of industrial production was produced by state controlled entities. Privately owned businesses were generally prohibited and trade with other countries was limited to items which could not be produced in China. The state goal was to have a self-sufficient economy. As there were no incentives for profits by firms and individual workers, there was little competition and the Chinese economy remained somewhat stagnant and was less than efficient. The standard of living for Chinese citizens was significantly lower than other developing countries. Just 35-40 years ago, more than a billion people survived on ration coupons living in poverty [1].

In 1976, Chairman Mao died. Shortly thereafter, in 1978, the government began to make changes and reforms to its economy. These changes moved the Chinese economy from a Soviet-style economy to one more aligned with free market principles. They opened up trade and investment in the West. Individual farmers were given ownership incentives and were allowed to sell some of their crops on the free market. Citizens were also encouraged to start their own businesses [10]. Many Chinese companies got their start at this time. They grew quickly without their previous collectivist or state-owned "parents."

Despite the state's encouragement of such free market enterprises, the mainstream political thinking at the time was still that capitalism was evil. Contrary to that, the owner of one such company delayed the start of his manufacturing business until he could first educate his employees to respect capitalism. During these early days of economic reform and rapid growth, there was little or no corporate theory or ideology of corporate ethics [1].

At this time, the government also began attracting foreign investment by removing trade barriers. The new economic policies were implemented slowly and piecemeal into just a few regions of the country at first, allowing the government to experiment with the effects of the reforms gradually before they were expanded further into the country [10]. From about 1978 to 2001 (prior to joining the World Trade Organisation), the economic environment in China was changing dramatically. According to [1], there was no specific effort to develop or improve business ethics as the country transitioned into more of a market driven economy. Changing economic policies led to much debate and critical thinking in the country about fairness and the reasonableness of the changes.

In 2001, China joined the World Trade Organisation (WTO). The WTO is the international organisation that deals with the rules of trade between nations. Membership in the WTO created increased scrutiny on Chinese business practices and ethics, both domestically and internationally. Major cultural change was occurring at this time as Chinese citizens began leaving behind many of the traditional Marxist views. Business ethics courses began to appear in MBA curriculums. The former Premier Zhu Rongji even declared that the new national accountancy schools would have the motto, "Don't Cook the Books" [1].

While many economic reforms have been made, China is still not a true free market economy. While the government does permit free market forces in some areas, the state is still in control of a significant amount of the economy. Lu presented the following anecdote (paraphrased) about the migration from a planned economy to a capitalist regime: In 2007 a man stole a pig, and then became very successful by investing the money obtained by selling the pig. First he bought an education, and then invested the rest in several ventures. There were many debates after this aired on television, debates about whether or not the thief should be prosecuted at all. It was pointed out that many jobs were created by his successful business ventures [1].

The switch to a market economy changed everything in China. So many people aspired to become rich in the new capital-driven and profit-seeking market that the former hero, King Lei Feng, who had dedicated his life to his people, was being replaced by China's new king - profits. Those few who cheated citizens and foreign customers would have still been working in factories if not for the reforms. They would not have been able to cheat, as Professor Richard T. DeGeorge pointed out, if the evils of free enterprise had not followed into China. The new capital-driven economy has brought the benefits and the biggest source of problems [1].

\section{HAS CHINA CHEATED THE US?}

According to the Oxford Dictionary, the definition of the word cheat is to act dishonestly or unfairly in order to gain an advantage. This paper will identify and discuss the three primary ways in which the Chinese government has been accused of cheating the US. Each will be defined and discussed to support the assertion of this paper, which is that China has "cheated" the US.

Most allegations of "cheating" by China can be categorised into one of three primary types of activities. To the extent that each of these activities constitutes acting dishonestly and unfairly to gain an economic advantage over the US, one can conclude that China is indeed cheating. These activities include: 1) the practice of "dumping"; 2) the exporting of inferior and/or dangerous products; and 3) the manipulation of currency exchange rates.

\section{A. Dumping by China}

One method of cheating, known as "dumping", amounts to selling products and services in a foreign market at prices lower than they are sold for in the domestic market or below the cost of production. One form of dumping is also referred to as predatory pricing. Such practices may damage the viability of producers of the product in the importing nation. Once these firms are forced out of the market, the prices will 
be increased. In the long run, dumping can seriously affect the economy of the importing nation by driving domestic suppliers out of business, resulting in higher unemployment rates. Yet another more subtle form of dumping (that is harder to identify) occurs when a foreign government subsidises the foreign company that is producing and selling the goods to US businesses and consumers. In this situation, the foreign supplier does not need to set the selling prices high enough to cover all the costs of production and delivery and therefore can sell at lower prices than their competitors. A foreign government may be willing to subsidise its corporations in order to stimulate its economy. In addition, the foreign government may also be the direct owner of the corporations that are dumping the goods.

The WTO's position on dumping has been to "reserve judgment" as to whether dumping is actually a form of cheating. However, the WTO does acknowledge the rights of a country to apply anti-dumping measures if the importing country can show evidence of significant negative effects on its domestic producers. In those cases, the WTO permits countries to take action against dumping activities such as imposing tariffs or duties on the offenders. The WTO spends a significant amount of time investigating countries accused of dumping.

In the United States, anti-dumping and countervailing duty (AD-CVD) laws have been in place for more than a hundred years [5]. These laws attempt to protect US farmers, corporations and consumers from such subsidies by imposing importation duties on foreign government-subsidised items. The general rule of thumb is that the duties are enacted to be equal to the government subsidies or to offset the value of the lost US sales due to the dumping activities [5].

Over a quarter of all the AD-CVD complaints to the WTO are against China [5]. The American Manufacturing Organisation has documented evidence that China has dumped many different types of items on the US economy, including shrimp, prawns, crawfish tail meat, garlic, honey, and wooden bedroom furniture. Steel is also an item that is commonly dumped by several worldwide players, including China. The US has imposed importation duties on several steel vendors including the country of China [6]. In 2008, the US imposed $700 \%$ tariffs on major Chinese steel pipe makers in retaliation for dumping and for government subsidies given to the Chinese steel companies. In 2009, United Steelworkers complained that the Chinese government was unfairly subsidising steel pipes, and new duties were placed on imports of steel pipes in response. The US government has also accused China of subsidizing paper products and of dumping auto parts and chickens. Complaints have also been filed by the US with the WTO over the sale of electric blankets. In December 2010, the WTO ruled that the US was entitled to impose duties against China to protect against the dumping of Chinese tires.

These examples are but a few of the many documented examples of Chinese dumping activities in the US. These represent unfair and dishonest ways of gaining an economic advantage, but the consequences can be even worse and more problematic if the goods are inferior or dangerous.

\section{B. Inferior Goods}

Another way to unfairly and dishonestly gain an economic advantage (cheat) is to "dump" inferior goods in the market. These goods have been manufactured at the lowest possible costs, resulting in poorly constructed items often made with dangerous or toxic materials. Such inferior goods, not up to US standards for manufacturing, will truly have lower costs of production than will competing goods made in the US. As these inferior goods have lower costs, they can be priced lower as well, which in turn has the same negative effect on US competitors as predatory pricing or dumping. In addition, cost-conscious consumers may unknowingly purchase inferior goods which in some cases can be dangerous or harmful to them.

In recent years, there have been many cases of poisonous or dangerous products being imported from China. One such example is the Chinese drywall. Defective drywall imported from China was shown to emit poisonous gasses and other substances which damaged copper pipes and wiring, etc., as well as to cause respiratory and other health problems from the owners of the homes built with this drywall. Multiple class action lawsuits have been settled and several are pending related to Chinese drywall [11].

Another example of dangerous items imported from China is toys tainted with excessive levels of lead paint. In 2007, multiple recalls of toxic toys occurred in the United States, and all of them were Chinese made. It is alleged that the Chinese used lead paint because it was significantly cheaper. Lead paint is extremely toxic, especially for children. Many believe that children's toys with a high level of lead content may be responsible for the rise of autism in the US [12]. Linklaters Toys was duped into using lead-based paint by a crooked vendor cutting corners after a certain color of paint ran out of supply. Zhang Shuhong committed suicide when his firm delivered a million toys with lead paint to the US. That paint vendor is now in seclusion [1].

Toothpaste imported from China was recalled because it contained diethylene glycol (DEG), a chemical that is dangerous for human consumption. The United States Food and Drug Administration advised US citizens to throw away Chinese toothpaste containing glycol. Today, China no longer uses glycol as a substitute for the more expensive glycerin in toothpaste. It is interesting to note that the price of this Chinese toothpaste was about one half that of its competitors when using glycol. However, that price difference has dwindled to a few cents since Chinese manufacturers stopped using the glycol [1].

Even pet food imported from China was found to contain a very dangerous chemical called Melamine. This chemical was blamed for the death of thousands of pets in the US. Although China accepted no responsibility and denied adding melamine to the wheat gluten, US chemists have irrefutable proof of the toxic chemical in the pet food. The melamine used in pet food produced by two small, but highly touted and respected, Chinese companies was believed to be done to achieve the required level of protein. China purposely exported the bad food under the category of "non-declared" goods, avoiding inspections and detection [1].

Aside from dumping low-priced and inferior or tainted goods on the US market, China has been accused of artificially holding its currency exchange rate at lower levels than would have naturally occurred in relation to China's 
main trading partners.

\section{Currency Manipulation in China}

In addition to subsidised product dumping and exportation of inferior products, China has also "cheated" the US by manipulating its currency's exchange rate with the US dollar. China has essentially "pegged" the Yuan's value to the US dollar instead of allowing it to move freely in foreign exchange markets. It did this partially by buying up large amounts of the US dollar and holding them in reserve. This affects the supply and demand of currency to keep the Yuan/dollar ratio at the desired level. China has plenty of cash to do this because of its trade surpluses with the US and other countries.

The Chinese currency is referred to as both the Yuan and the Renminbi, which translates to, "the people's currency." It is abbreviated "RMB" and stayed fixed against the dollar for many years [7].When a currency stays fixed against the dollar, this does not mean its value is the same as the dollar but only that its value goes up if the dollar goes up - and goes down if the dollar goes down. n other words, the currency will not lose ground against the dollar, or gain ground. If the currency were allowed to float freely, then one would expect its value relative to the dollar to change occasionally. It has been clearly shown that undervaluation of the currency (a high real exchange rate) stimulates economic growth. This is true particularly for developing countries, with China's undervaluation very evident in its large current account surplus [8].

In 2005, China modified its exchange rate regime, basing it on a weighted-average basket of other currencies but kept the weighting percentages secret. Using regression techniques, [7] determined that the weight of the dollar was approximately 100 percent of the base.

The International Monetary Fund (IMF) contains Articles of Agreement to stop any country from manipulating its currency for unfair advantage. The IMF only rarely calls out a country for defeating its currency, having done so only twice - but ironically it has made accusations of inflating currency values hundreds of times [7]. The IMF has been accused of sloppy work, and so it adopted a new surveillance decision in June, 2007 which is expected to improve its effectiveness. In 2005 , the IMF was accused of being "asleep at the wheel" when there was supposedly much more currency manipulation than identified by the IMF [13].

Inside the US, efforts are exerted to identify and stop currency exchange rate manipulation. Since 2003, US representatives have applied intense and constant pressure on China to stop manipulating its currency downward from the higher levels it would have attained if allowed to move freely. US officials maintain that China manipulates its currency in order to increase its exports. When Chinese goods are cheaper, due to the devalued Yuan, then foreign customers find them more attractive.

Since 1988, the US Treasury has been legally required to report to Congress, twice yearly, any trading partners who are suspected of manipulating the foreign exchange rate [7]. Every report from October 2003 (an election year) to the 2007 reports, included China on the list of those countries guilty of manipulating currency values [7].
The world is economically correct in calling for China to cease manipulation of its currency. Periods of rapid growth, as China has experienced, should be associated with real exchange rate increases, not decreases. The "Balassa-Samuelson hypothesis" explains that economic growth arises from relative tradable productivity gains. The gains cause rising relative prices. In the case of China, however, productivity and prices are consistent with the hypothesis while its real exchange rate did not appreciate from 1990 to 2006 [14].

This paper has discussed the three primary ways in which China has been accused of cheating: dumping, inferior products and currency manipulation. The next section of this paper will address some additional noteworthy observations of the unfair and unscrupulous economic climate in China.

\section{Other Financial Market Issues in China}

Certain malevolent acts of fraudulent financial reporting, poor auditing standards, unfair actions by bond underwriters, and concern that the listed firms on the Chinese stock exchanges may be violating the public trust, all suggest problems in the Chinese economy with regards to honesty and ethical behavior. The United States is negatively impacted in the sense that the equity markets are global, and investors anywhere can be affected.

Several examples of corporate fraud by Chinese companies have come to light in recent years. Deloitte, Touche, \& Thomatsu exposed the fraud of their own client, Longtop Financial Technologies, a Chinese financial software company. In the audit of Longtop, Deloitte uncovered the fact that Longtop's local bank personnel had provided false bank confirmations, attesting to the existence of non-existent cash balances. The real depth of this crime, however, extended to the world class underwriting teams potentially involved in Longtop's schemes. Longtop went public in 2007 with Goldman Sachs and Deutsche Bank as the key underwriters, and with Morgan Stanley as the lead manager of the offering. Just two weeks before the bank confirmation scandal began to unfold, Carol Wang of Morgan Stanley highly touted Longtop's stock saying that its low price (caused by the fraud allegations) created a valuable entry position for all prospective investors. This shows that the underwriting team continued to hawk the stock in the face of proven allegations of fraud [15].

In a separate case, Deloitte also resigned and withdrew from an audit of China Media Express over suspicious bank confirmations [15].

In another example, the foreign offices of Deloitte, Ernst \& Young, KPMG, PWC, and BDO that service Chinese firms decided not to cooperate with the SEC as it pursued accounting investigations into nine Chinese companies whose shares are also traded in the US. The CPA firms claim Chinese law does not allow them to supply documentation in the wake of fraud allegations [16]. According to one partner, the Chinese state owns all the working papers created by the accountants, and the papers are never allowed out of the country.

Goldman Sachs Investment Management had an eight percent stake in Chinese chemical company, ShengaTech, when KPMG refused to sign the 2010 annual report in 2011 , 
and then resigned from the audit in late April. KPMG apparently did this after receiving false confirmation letters from banks [15].

The most embarrassing Chinese auditing moment was to come later in 2011 after China Integrated Energy engaged KPMG in December. Hiring this Big Four audit firm was a huge "pillar of validation" that enabled China Integrated Energy to raise US\$ 24 million from US investors interested in its biodiesel business. Early in 2012, KPMG signed off on the financial statement audit; however, six months later it had to recant its opinion when the Chinese executives of the company refused to answer questions as to whether the whole firm was anything more than just a hoax [15].

The capital markets themselves are also well known for fraud by China's listed companies. In the thirteen years leading up to 2007, almost 600 enforcement actions were carried out by the China Securities Regulatory Commission (CSRC). The CSRC keeps watch over both of the Chinese stock exchanges: Shanghai and Shenzhen.

And the fraud trend seems to be increasing. Like the US's NYSE, these two exchanges are self-regulated for the most part. The rules for self-enforcement have been updated a few times since 1997 with CSRC approval, leading up to the year 2006. There is no requirement to disclose publicly the enforcement actions taken, and there is no authority vested in the CSRC to impose any fines on the wrongdoers [17]. This may be a sign of a weak system that can be taken advantage of by unscrupulous firms.

Interestingly, China controls almost eighty percent of the listed firms on its exchanges and actually owns half of them [18]. The influences of the state will stay strong in the area of financial and legal regulation. This will seem to naturally undermine independence in the regulatory and judicial areas [19].

\section{Chances of Future Fair Play by China}

\section{A. Recent Updates on China-US Trade Statistics}

There are signs that the Chinese government has begun to respond to pressures to allow more movement in their currency. The USA Weekly reported in February 2013 that the Yuan had increased against foreign currencies [20]. He reports that continued increase in the value of the Chinese currency will hurt the Chinese exporters at a time when the Eurozone is trying to recover from its debt crisis, and from the overall global economic fears.

In 2012, China's foreign trade increased by $6.2 \%$ from the year before, although it missed the projected growth rate of ten percent. Its exports are half of the country's sales. According to [20], the US replaced the European Union in 2012 to become the most common destination for Chinese exports, to the tune of US\$352 billion which is an increase of 8 percent from 2011. China's trade surplus with America grew about 8 percent in 2012, up to US\$219 billion.

Forty-one percent of the US accusations of dumping and subsidy claims in 2012 were against China. In 2012, the US Department of Commerce imposed an additional 154\% duty on food additives like xanthan gum. The producers, who make $70 \%$ of the world's food preservatives, may pull out of the US. According to [20] China will be focusing on emerging markets going forward - hoping to make up for the flattening growth of exports to its major trade partners.

\section{B. The Obama Administration}

As Henry Paulson claimed, the Obama administration must stay engaged with China - following suit with actions by the Bush administration. Engagement face to face is the only way to establish long-term agreement [21]. Perhaps Hillary Clinton had this in mind when she told the China, while she was in Beijing in February 2009, that there were more opportunities for the US and China to work together, than between the US and any other country [22].

After the initial surge in ethics reforms, the Obama administration should not expect China to revisit those aspirations in the near future. The administration will likely keep the US long-term goal of fair exchange rates with Beijing. However, they must proceed with caution because an ultimatum on this issue could harm the US gains that have been made in terms of closer ties with China [22].

There are continued claims in 2013, by Congressmen on both sides of the aisle and by business groups, that China is still manipulating the Yuan. However, the official party line of the Obama administration is that China is not currently manipulating its currency's relative value. The US Treasury said that even though the Yuan remained significantly undervalued in mid-April 2013, China is not guilty of currency manipulation [23], [24]. In the last three years the Yuan gained about $10 \%$ in value against the Dollar - as the Treasury recently wrote in its semi-annual report to Congress. Jack Lew, Obama's new Treasury Secretary immediately went to China on his first international trip following his appointment to his new post. He visited with the new president, Xi Jinping discussed various issues including allowing the Yuan to rise against the Dollar.

\section{SUMMARY OF SIGNIFICANT FINDINGS}

China has progressed from a Marxist state-run dictatorial existence towards a market-based economy, but the transition is incomplete. This country has experienced significant growth in GDP with annual growth rates ranging from $8 \%$ to $17 \%$ for decades. There are definite signs of capitalism beginning to take root, but there are still many signs of governmental control. In 2012 the US replaced the EU to become the number one destination of Chinese exports and China's trade surplus against the US grew by $8 \%$ to US $\$ 219$ billion.

This paper concludes that China has cheated the US. They have done so in three primary ways: First, there is strong evidence that China has dumped goods on the US at prices lower than the costs of production of those goods. The WTO and US Department of Commerce have continuously sanctioned China for dumping activities and have levied significant tariffs and duties on Chinese furniture, steel, food products, and much more. Second, there is strong evidence that China exported contaminated goods to the US including drywall, toothpaste, pet food, and toys for toddlers with lead paint. The goods were manufactured in an inferior manner in order to lower costs and therefore prices, which have the same 
economic effect as dumping. Third, strong evidence exists that China had fixed the value of its currency to the US dollar for many years. By defeating its currency, China has acted in an unfair manner to gain an advantage in the world economic market. This situation is being monitored by the IMF.

In addition to these three primary means of cheating, this paper noted that the overall business climate in China is somewhat unethical and questionable. CPA firms, investment banks, and commercial banks are not totally free of mistrust for their actions in China, and the financial markets are far from being independent of the government at this point.

As we revisit the question: Did China cheat the US? Please recall that the definition of the word cheat (Oxford Dictionary) is to act dishonestly or unfairly in order to gain an advantage. Due to the fact that dumping, inferior products and currency manipulation each represent dishonest or unfair activities engaged in for the purposes of gaining an economic advantage, it is the conclusion of this research, that yes, China did indeed cheat the US.

\section{REFERENCES}

[1] X. Lu, "A Chinese perspective: Business ethics in China now and in the future," Journal of Business Ethics, vol. 86, no. 4, pp. 451-461, June 2009.

[2] C. Bergsten, "A partnership of equals: How Washington should respond to China's economic challenge," Foreign Affairs, vol. 87, no. 4, pp. 57-69, July-August, 2008.

[3] J. Moon and X. Shen, "CSR in China research salience, focus and nature," Journal of Business Ethics, vol. 94, pp. 613-629, 2010.

[4] P. Ip, "The challenge of developing A [sic] business ethics in China," Journal of Business Ethics, vol. 88, issue 1, pp. 211-224, April 2009.

[5] G. Mastel, A. Szamosszegi, J. Magnus, and L. Chimerine, "Enforcing the rules," The Alliance for American Manufacturing, p. 9, 2007.

[6] S. Rohini, "Anti-dumping probe: A case study in steel," Economic and Political Weekly, vol. 36, no. 48, pp. 4447-4449, December 1-7, 2001.

[7] J. Frankel and S. Wei, "Assessing China's exchange rate regime," Economic Policy, vol. 22, no. 51, pp. 575-627, July 2007.

[8] D. Rodrik, "The real exchange rate and economic growth," Brookings Papers on Economic Activity, vol. 2008, pp. 365-412, Fall 2008.

[9] F. Norris. (May 26, 2011). The audacity of Chinese frauds. The New York Times. [Online]. Available: http://www.NewYorkTimes.com

[10] W. M. Morrison, "China's economic rise: History, trends, challenges, and implications for the United States," Congressional Research Service, pp. 7-5700, 2013.

[11] Associated Press. (February 9, 2013). Settlements over toxic Chinese drywall OK'd. Herald-Tribune. Sarasota FL. [Online]. Available: http://www.heraldtribune.com/article/20130209/ARTICLE/30209999 6

[12] P. Kavilanz, China to Eliminate Lead Paint in Toy Export, September 11, 2007.

[13] A. Kishore and D. Mohanty, "How effective will the IMF's new surveillance framework be?" Economic and Political Weekly, vol. 43, no. 18, pp. 31-36, May 3-9 2008.
[14] R. Tyers and J. Golley, "China's real exchange rate puzzle," Journal of Economic Integration, vol. 23, no. 3, Special Issue, pp. 547-574, September, 2008.

[15] F. Norris. (April 5, 2011). Indian accounting firm is fined $\$ 7.5$ million over fraud at Satyam. The New York Times. [Online]. Available: http://www.NewYorkTimes.com

[16] J. Gallu and E. Himaras. (December 4, 2012). SEC accuses big four chinese affiliates of blocking probes. Bloomberg News. [Online]. Available: http://www.BusinessWeek.com.

[17] C. Jia, S. Ding, Y. Li, and Z. Wu, "Source fraud, enforcement action, and the role of corporate governance: evidence from China," Journal of Business Ethics, vol. 90, no. 4, December 2009.

[18] G. Chen, M. Firth, and L. Xu, "Control transfers, privatization, and corporate performance: efficiency gains in China's listed companies," Journal of Financial and Quantitative Analysis, vol. 43, pp. 161-190, 2008.

[19] W. Hou and G. Moore, "Player and referee roles held jointly: the effect of state ownership on China's Regulatory Enforcement against fraud," Journal of Business Ethics, vol. 95, pp. 317-335, 2010.

[20] Y. Yiqi, "Trade in the balance-tough times ahead for China's Exports as global uncertainties continue," USA Weekly, pp. 14-15, February $1-7,2013$.

[21] H. J. Paulson, "A strategic economic engagement: strengthening U.S.-Chinese ties," Foreign Affairs, vol. 87, no. 5, pp. 59-77, September-October, 2008.

[22] E. Economy and A. Segal, "The G-2 Mirage: Why the United States and China are not ready to upgrade ties," Foreign Affairs, vol. 88, no. 3, pp. 14-23, May-June 2009.

[23] D. Scissors, "Deng undone: The costs of halting market reform in China," Foreign Affairs, vol. 88, no. 3, pp. 24-39, May-June 2009.

[24] V. Needham, "Treasury: China not manipulating currency: on the money," The Hill's Finance \& Economy Blog, pp. 1-29.

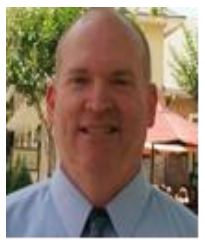

Greg Carrington is a graduate student at Sam Houston State University. His undergraduate degrees are in finance and accounting from Sam Houston State University. His career area are in private and public sector accounting, internal controls, and auditing.

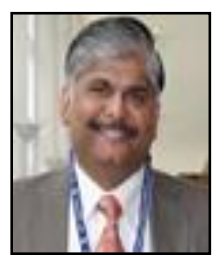

Balasundram Maniam is a Minnie Stevens Piper professor and Texas State University System Regents professor of finance at Sam Houston State University, USA. He obtained his Ph.D degree in finance from University of Mississippi. He has published over 150 peer-reviewed journals and presented on over 250 international and national conferences.

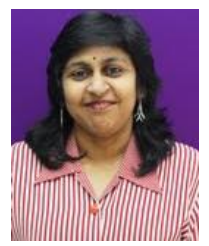

Geetha Subramaniam is a senior lecturer in economics at the Faculty of Business Management, Universiti Teknologi MARA, Shah Alam, Malaysia. She obtained her Ph.D degree from Victoria University of Wellington, New Zealand in the area of development and economics. Her research interests include labour economics, women issues and development economics. 